\title{
3D LASER SCANNING OF THE HISTORIC GREEK CATHOLIC CHURCH - CASE STUDY
}

\author{
Ing. Matúš Tkáč; doc. Ing. Peter Mesároš, Ph.D.
}

\begin{abstract}
Laser scanning is the most modern technology for high quality focusing on real objects. 3D laser scanning technology allows the space digitizing of objects which means transferring different objects from the real world into a 3D digital environment where they can continue to work. 3D object scanning allows enhancing the design process, speeds up and reduces data collection errors, saves time and money and thus makes it an attractive alternative to traditional data collection techniques. This technology has wide application and it can be used for surveying of various objects such as buildings, factory buildings, machinery, equipment, engineering networks and also cultural monuments or statues. The result of a scan is a $3 \mathrm{~d}$ model point cloud which represents threedimensional image of scanned objects and complex shapes. The aim of the paper is description of methodology of the work with 3D laser scanner Faro Focus X130 from Faro Company on the real building object - historic greek catholic church. This paper describes the methodology of laser scanning, describes the specific step during scanning and describes the possibility of create 2D documentation from 3D model point clouds.
\end{abstract}

Key words: 3D laser scanning, terrestrial laser scanning (TLS), point cloud, historic buildings, digital methods

\section{INTRODUCTION}

Technology is rapidly developing in the Surveying world today. [1] In recent years, the use of terrestrial laser scanning (TLS) technique in engineering surveys is gaining an increasing interest due to the advantages of non-contact, rapidity, high accuracy and large scale. This technique delivers millions of accurate 3D points (mm level accuracy) with a very high point density in a short time (up to 1 million points per second), which makes it a valuable alternative or complementary technique for classical topographical measurements based on total station or digital photogrammetry. The terrestrial laser scanning can still deliver very accurate points even in the situations where other topographical techniques are difficult or impossible to use. [2] It has become widely used in a range of applications including building modelling, architecture, deformation modelling, mining surveys and volumes as well as crime scene analysis. 3D Laser Scanning of solid objects such as buildings has proven to be an effective method of capturing data and modelling buildings for heritage or remodelling purposes. Typically TLS instruments have been used in industries such as architecture, engineering, construction, manufacturing, structural monitoring, heritage preservation, forensics and virtually all capital projects requiring rigorous design processes. It is also capable of safely acquiring data that cannot always be easily accessed such as bridge beams, rock faces and highway information. [1] TLS has been proven effective in urban mapping for applications ranging from as-built documentation to the three-dimensional (3D) reconstruction of architectural details and building facades. [3] Some of the main benefits of TLS data acquisition is the increased speed of data capture, accuracy of plans, elevations, profiles, volumes and area calculations able to be extracted from scans. [1] Terrestrial laser scanning technology is very well applied in the preparation and processing of documentation revitalization monument restoration in architecture. Surveying the real state it is carried out for purposes of drafting the project of realization which documents the extent of restoration of historic building. These visualization of historical monuments are integrated into digital presentations that are used for a variety of decision-making studies. [4] 


\section{METHODOLOGY OF LASER SCANNING}

Process scanning consist of:

I. Determine the scanning object

II. Deployment of identical reference spheres

III. Setting the laser scanner

IV. Setting the scanning parameters

V. Location of the laser scanner + Start scanning (automatic process)

i. Determine the scanning object

This church is located in a small village Hačava which is situated in the Slovak Karst. The sacral dominant in Hačava is Greek Catholic church of the Nativity of the Blessed Virgin Mary from the 18th century. The church was built in the period of artistic directions of Baroque and Classicism. [5]
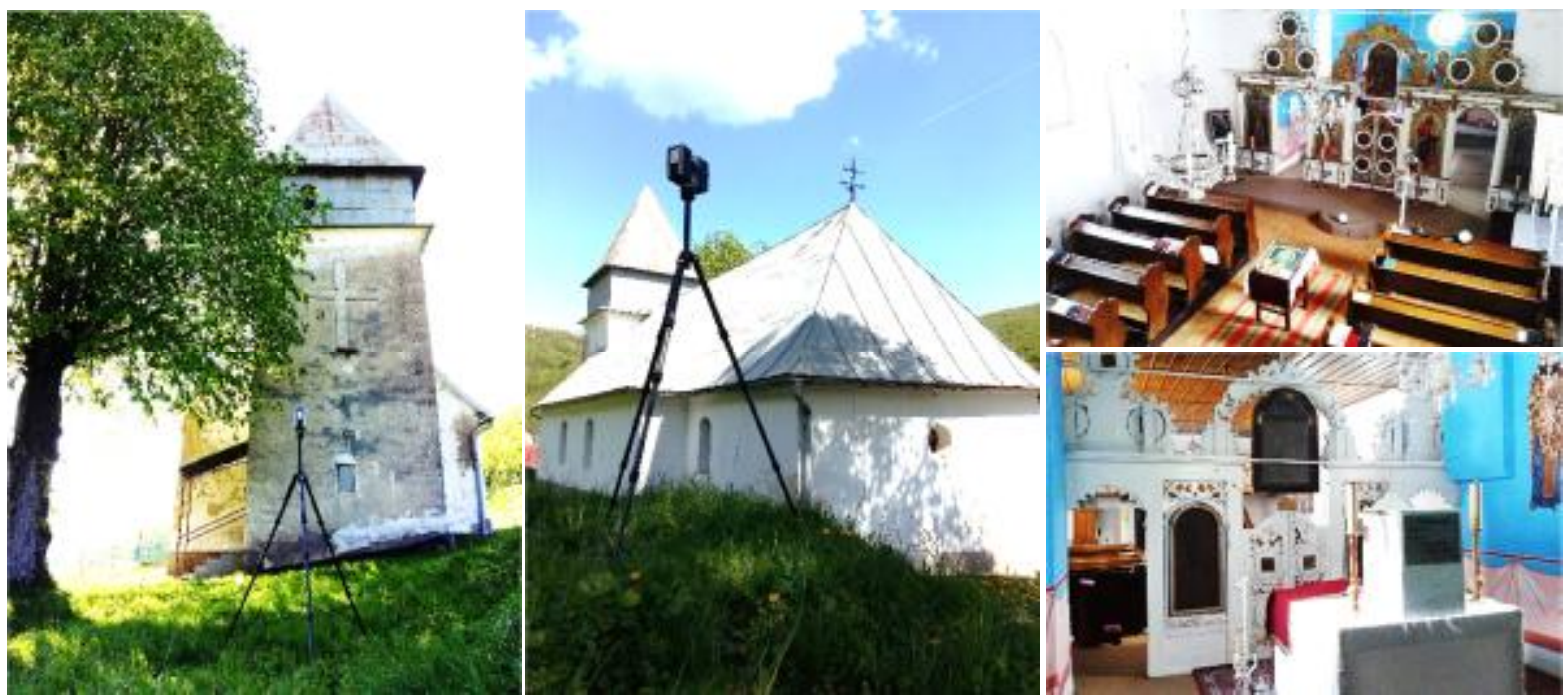

Fig. 1 Nativity of the Blessed Virgin Mary Greek Catholic Church- Hačava

\section{ii. Deployment of identical reference spheres}

Deployment of reference points is a step preceding the process of scanning. References, or targets, are used to register multiple individual scans that are each on their own coordinate system, onto a single, aligned coordinate system. Although scan registration can be done purely on the basis of natural targets, such as planes, walls, corners etc., it is recommend to enhance the scanned environment with additional artificial reference objects, like spheres. In principle, the reference sphere are reference points or places that serve the registration of individual scans. [6]

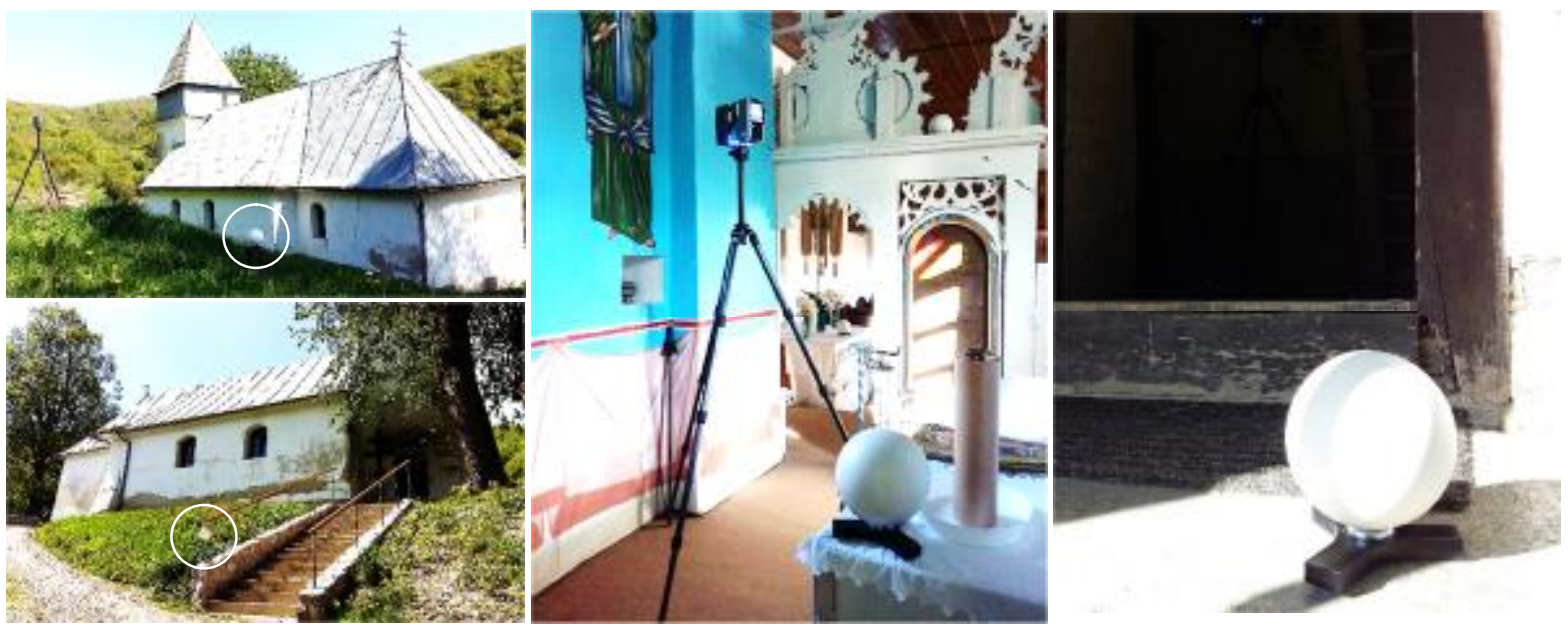

Fig. 2 Deployment of reference spheres 
The spherical shape allows the highest possible scanning efficiency from various directions. [7] Mathematically it need three corresponding references in the two scans which you like to register to each other. But a higher number of references per scan may improve the registration results and may make registration easier and less error prone. Reference spheres should be completely visible in the scan. They should form a polygon around the scanner and have varying distances to the scanner. They have to be in the scanning area at varying heights, distances and planes. [6]

\section{iii. Setting the laser scanner}

Before the scanning process must make the following basic settings:

- Setting up the tripod and mounting the laser scanner

- Setting a horizontally plane of the scanner

B To balance the laser scanner can use either a bubble inclinometer at the tripod or the inclinometer on the scanner screen. [6] The laser scanner must be in the plane in each new positions.

iv. Setting the scanning parameters

Scanning parameters are the parameters used by the scanner for recording the scan data. The main parameters include: [4]

B Creating a scan project (project name, the name of the individual scans,...)

B Selecting a scan profile

- Indoor (to $10 \mathrm{~m}$, over $10 \mathrm{~m}$ - in our case)

- Outdoor (to $20 \mathrm{~m}$, over $20 \mathrm{~m}$ - in our case)

B Setting resolution and quality

$\circ$ Resolution: $1 / 1,1 / 2,1 / 4,1 / 5,1 / 8,1 / 10,1 / 16,1 / 20$ and $1 / 32$

○ Quality: $1 \mathrm{x}, 3 \mathrm{x}, 4 \mathrm{x}, 6 \mathrm{x}, 8 \mathrm{x}$
- In our case: Indoor:
Outdoor:
1/5 - 4x; scan time - approximately 08: 40
1/4 - 4x; scan time - approximately 11:15

B Color settings and various general settings

\section{v. Locations of the laser scanner + Start scanning}

If is the scanner in the first position, it can start scanning process which is automatic. During scanning, the scanner rotates clockwise by $180^{\circ}$. If it is scanning with color, the scanner will continue to turn to $360^{\circ}$ to take the pictures. These color images are used to measured data were true color. Now, it may move the scanner to the next scan position and start a new scan. [6]

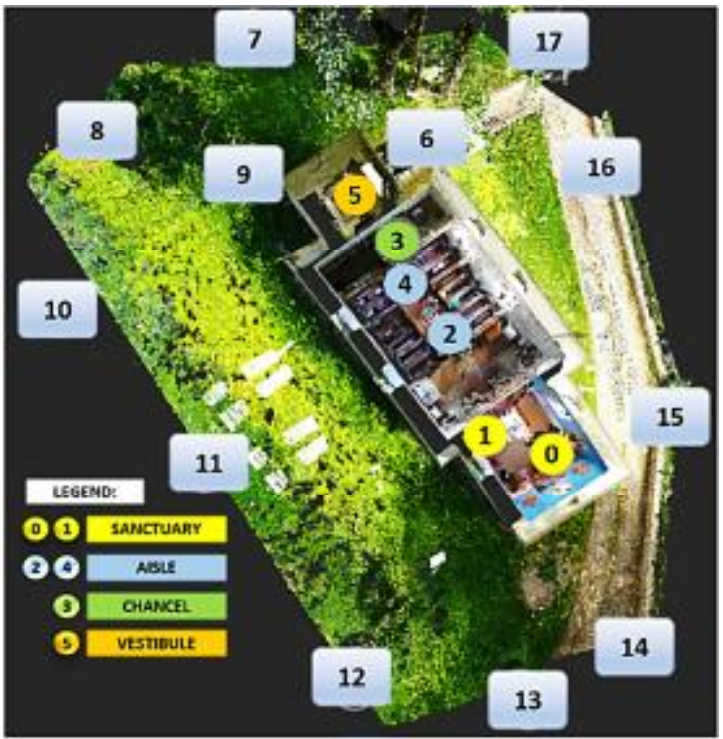

Fig. 3 Eighteen positions of the laser scanner
The aim of the laser scanning was interconnection of interior and exterior. In this case, it didn't matter if the first position of the laser scanner was indoors or outdoors. We decided that the first position of the scanner will be in the interior. We started in the sanctuary where were two positions of the scanner $(0 ; 1)$. We continued to the third position (2) in the aisle and fourth position on the chancel (3). Positions five (4), six (5) and seven (6) were very important because they allowed interconnection between interior and exterior. Views from this three positions are displayed in Figure 4. Interconnection through the windows was very complicated eventually unrealistic. This was a very specific and very important step during scanning. 
In the exterior we then continued around an object. The total scan time was five hours. These five hours consisted of installing the scanner, deployment of reference spheres, changes in positions of the scanner, from settings plane in each new position of the scanner and from scanning process which was completely automatic. The positions of the reference points were often different because we had available just twelve pieces of reference sphere and couldn't be deployed so that their position didn't change.

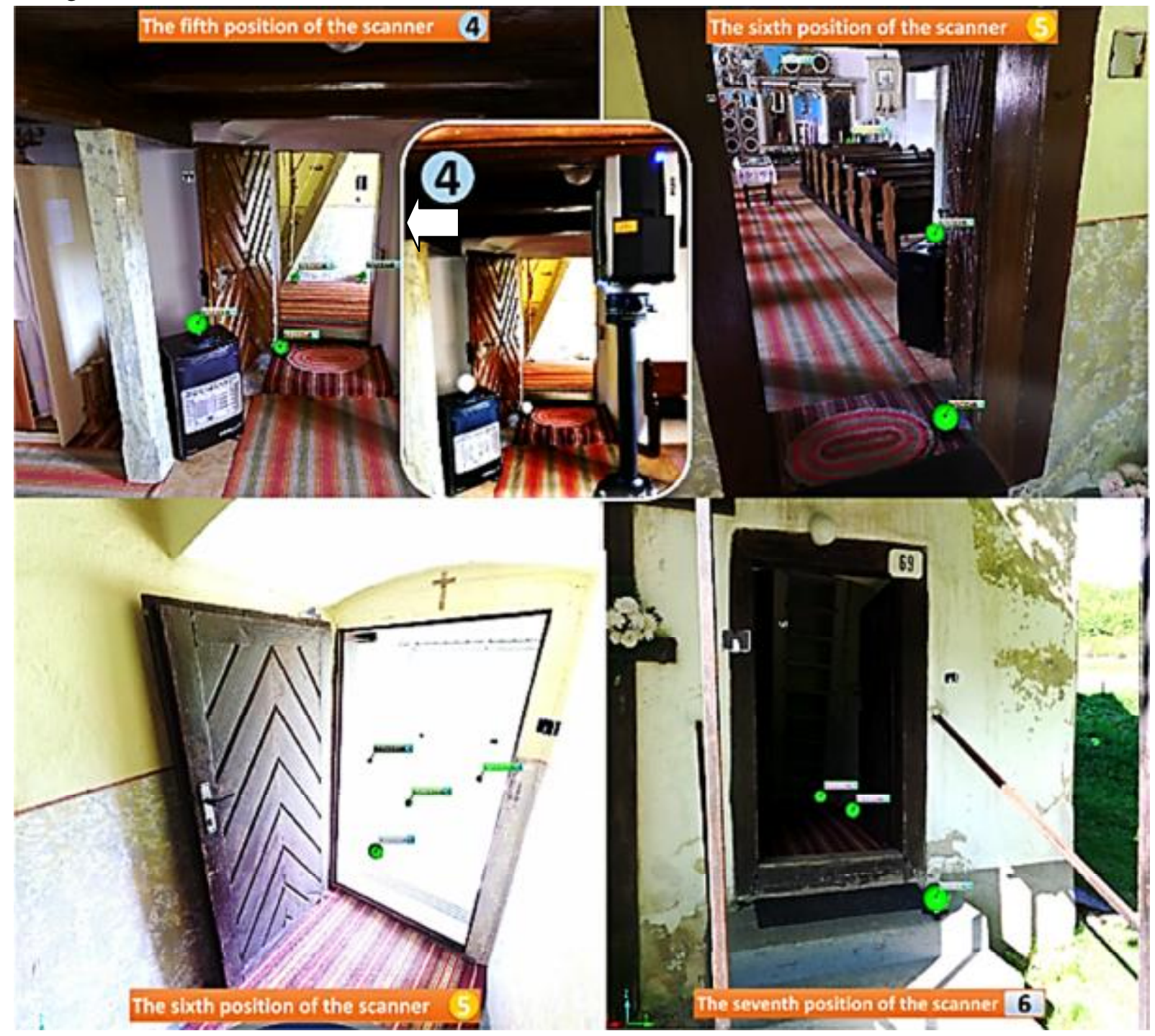

Fig. 4 Interconnection between interior and exterior

\section{FROM 3D LASER SCANNER DATA TO 2D PLANS}

Historical buildings like this often don't currently have the project documentation. The technology of laser scanning offers the possibility of creating 2D documentation from 3D model point clouds, but very important step is to interconnection interior and exterior. Without this step is impossible to generate the thickness of the walls in technology of laser scanning. In this case, to create a 3D model of point clouds was used software Faro SCENE. The software Faro SCENE has been specially developed for the laser scanner Faro Focus3D. The function of this program is to prepare and manage laser scans generated by laser scanner FARO. The program offers registration which consist of three steps and it designation of reference spheres, interconnection of reference spheres and completion of the registration. Next this program offers simple measurements, coloring the point clouds, deleting redundant points, export of point clouds to various formats or creation of virtual tours. [8] 
These were the steps that preceded the creation of a 3D model point clouds which you can see in Figure 5 - A. To get the floor plan of this church we had to export this project in the format RCP into other software which was PointSense Building. PointSense Building will be applied where 2D plans must be generated from 3D plans in a short period of time, e.g. for property planning, property survey for facility management or for interior fitting and special construction. This software provides numerous tools for efficient, semiautomatic drawing and plan design. The product supports almost all laser scanner formats on the market. Disturbing items such as trees or furniture can be cut out of the point cloud easily. Floor plans from any height and sections from any position can be generated efficiently. [9]

On Figure 5 - B you can see the result and meaning interconnection of the interior and exterior of laser scanning for the purpose of creating 2D documentation. The floor plan on the figure 5 - B isn't standard floor plan which is made up of building lines. Is it the floor plan which is always made up from point clouds and now it is necessary to mechanically retrace lines point clouds classical building lines. This step is called horizontal tracing. This step is a strong tools for planning engineers, architects and designers because now they have accurate dimension of the present condition. This object was scanned twice in total and the difference you can see again on picture 5 - B; C. In order to calculate the facade was scanned only exterior but this view isn't applicable when creating $2 \mathrm{D}$ documentation. This view can be seen in Figure $5-\mathrm{C}$. Other options which allows the software PointSense Building to create $2 \mathrm{D}$ design documentation are as follows:

Specific commands for doors, staircases, niches or pillars speed up the drawing of floor plans. For example, five clicks or less is enough to generate doors, and their accompanying dimensions. Planes can be extracted from the point cloud automatically and provide edges and corners through spatial joining. Using built-in area management tools, intelligent room polygons can be generated quickly and comfortably from created outline plans. This clear and adaptable structure view makes areas more manageable and room dimensions for usable space clear. With the click of a button, graphical visualizations, room tags and reports can be generated with information such as surface area of rooms, floor types, room usage, etc. [9]

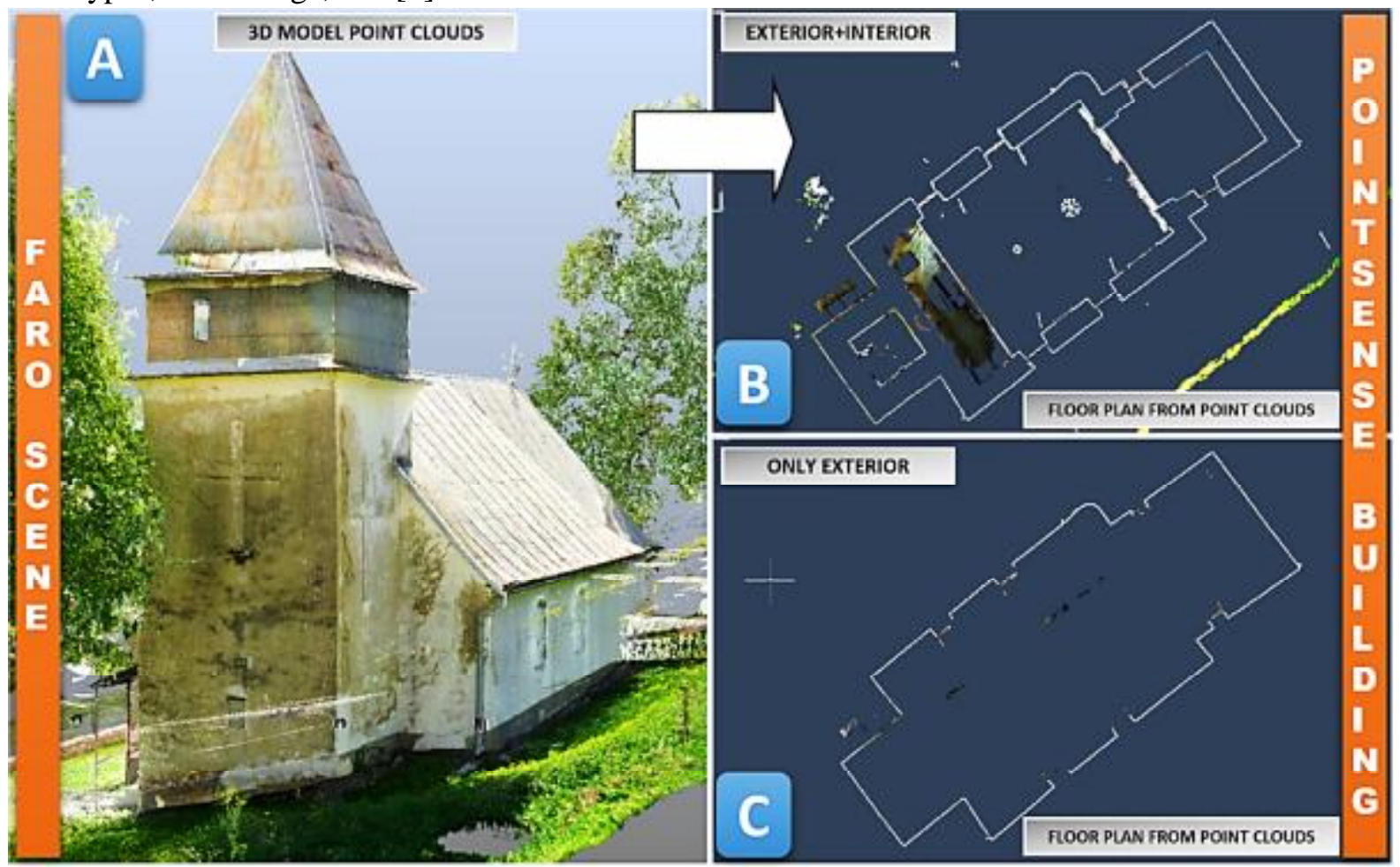

Fig. 5 A - 3D model point clouds; B - floor plan (exterior+interior); C - floor plan (only exterior) 


\section{CONCLUSION}

The main objective of this paper was to point out the technology of 3D laser scanning. 3D laser scanning is in civil engineering probably today the most progressive non-contact method for surveying real state. How object for $3 \mathrm{~d}$ laser scanning was used historic church in a small village Hačava. The first part of this paper describes concise the methodology of 3D laser scanning on the place scanning and describes a specific step during scanning and it is interconnection between exterior and interior. The second part of this paper describes the possibility of creating $2 \mathrm{D}$ project documentation from $3 \mathrm{D}$ model point clouds. This article showed that laser scanning is an effective tool for surveying the real state in civil engineering and in particular it is a strong tool for surveying historical buildings.

\section{Acknowledgements}

The article presents a partial research result of project VEGA - 1/0677/14 „Research of construction efficiency improvement through MMC technologies".

The article is the result of the Project implementation: University Science Park TECHNICOM for Innovation Applications Supported by Knowledge Technology, ITMS: 26220220182, supported by the Research \& Development Operational Programme funded by the ERDF.

\section{Literature}

[1] STANLEY, Thomas: Assessment of the FARO 3D Focus Laser Scanner for Forest Inventory: Dissertation thesis. University of Southern Queensland, 2013. Pages 86. [citované 2016-0523]. Dostupné na:

$$
\text { 〈https://eprints.usq.edu.au/24708/1/Stanley_2013.pdf> }
$$

[2] WANG, Weixing et al.: Applications of terrestrial laser scanning for tunnels: a review. In: Journal of Traffic and Transportation Engineering (English Edition). Volume 1, Issue 5 (2014), Pages 325-337. [citované 2016-05-23]. Dostupné na:

<http://www.sciencedirect.com/science/article/pii/S2095756415302798>

[3] KANG, Zhizhong et al.: Automatic Registration of Terrestrial Laser Scanning Point Clouds using Panoramic Reflectance Images. [online]. 2009. [citované 2016-05-23]. Dostupné na:

<http://www.ncbi.nlm.nih.gov/pmc/articles/PMC3348833/>

[4] PUKANSKÁ, Katarína et al.: Dokumentácia kultúrnych pamiatok - laserové skenovanie a digitálna fotogrametria. [online]. 2008. [citované 2016-05-24]. Dostupné na:

<http://www.obnova.sk/clanok/dokumentacia-kulturnych-pamiatok-laserove-skenovaniedigitalna-fotogrametria>

[5] Rožňava a okolie...: Hačava. [online]. [citované 2016-05-25]. Dostupné na:

〈http://www.retep.sk/okolie/hacava/hacava.php>

[6] FARO Laser Scanner Focus ${ }^{3 \mathrm{D}}$ X130. 2014. [citované 2016-05-25]

[7] Laser Scanner Reference Sphere Set (UltraX). [online]. [citované 2016-05-26]. Dostupné na: 〈http://shop.laserscanning-europe.com/Laser-Scanner-Reference-Sphere-Set-UltraX $>$

[8] IQservices.eu: Software. [online]. [citované 2016-05-28]. Dostupné na:

$<$ http://www.iqservices.eu/en/software/faro-scene.html $>$

[9] PointSense Building: Software for surveying and as-built documentation. [online]. [citované 2016-05-30]. Dostupné na:

<http://gb.faro3dsoftware.com/CAD/Products/PointSense/3D Laser_Scanner_Building.php $>$ 